\title{
Ferrobrucite synthesis and reactivity under hydrothermal conditions below $150^{\circ} \mathrm{C}$
}

WILLIAM CARLIN ${ }^{1}$, BENJAMIN MALVOISIN ${ }^{2}$, FABRICE BRUNET $^{3}$, BRUNO LANSON ${ }^{2}$, NATHANIEL FINDLING ${ }^{4}$, MARTINE LANSON ${ }^{4}$, TIPHAINE FARGETTON ${ }^{5}$, LAURENT JEANNIN $^{5}$ AND OLIVIER LHOTE $^{6}$

${ }^{1}$ ISTerre/ENGIE

${ }^{2}$ ISTerre

${ }^{3}$ Université Grenoble Alpes

${ }^{4}$ ISTerre-UGA

${ }^{5}$ Storengy

${ }^{6}$ ENGIE Research

Presenting Author: william.carlin@univ-grenoble-alpes.fr

Ultramafic rocks exposition to hydrothermal fluids in the 150$350^{\circ} \mathrm{C}$ range induces the formation of hydrated phases, typically serpentine minerals and ferrobrucite (i.e. serpentinization). Serpentinized ultramafic rocks exhumed to the surface can encounter further alteration when exposed to sub-surface aqueous fluids. Observations in natural samples suggest that ferrobrucite is more sensitive to post-serpentinization alteration than the other reactions products. Moreover, ferrobrucite is the main ferrous iron host among the products of serpentinization, and its alteration if coupled to iron oxidation could thus lead to hydrogen $\left(\mathrm{H}_{2}\right)$ production at low temperature. We study here the hydrothermal alteration of $\mathrm{Mg}_{0.8} \mathrm{Fe}_{0.2}(\mathrm{OH})_{2}$ at temperature below $150^{\circ} \mathrm{C}$. Thermodynamic calculations indicate that ferrobrucite is not stable at these temperatures and should react to form ironpoor brucite, magnetite and $\mathrm{H}_{2}$. We test these predictions by reacting synthetic ferrobrucite in hydrothermal conditions at $\mathrm{T}<150^{\circ} \mathrm{C}$. Synthetic ferrobrucite is produced under anoxic conditions by mixing iron and magnesium salts with sodium hydroxide. We investigate the influence of salt composition (chlorure or sulfate) and salt/sodium hydroxide ratio on the size and the homogeneity of the synthetic ferrobrucite. Rietveld analysis of x-ray diffraction reveals that the produced synthetic brucite is similar in size $(\sim 25 \mathrm{~nm})$, crystallographic structure and composition to ferrobrucite observed in samples from the Oman Drilling Project. Synthetic ferrobrucite is then reacted in hydrothermal conditions at temperature below $150^{\circ} \mathrm{C}$ for run durations of up to 31 days. The reaction products are characterized with $\mathrm{x}$-ray powder diffraction (Rietveld refinement), thermogravimetric analysis and scanning electron microscopy. They consist in magnetite, a layered double hydroxide (pyroaurite) and a ferribrucite-like mineral (i.e, containing abundant $\mathrm{Fe}^{3+}$ ). The progressive transformation of ferro- to ferribrucite is accompanied by a unit-cell contraction which likely result from iron oxidation. Processes accounting for charge balance in the ferribrucite structure are proposed based on Rietveld refinement data. Furthermore, a competition between magnetite and ferribrucite formation from ferrobrucite alteration is found for temperatures below $150^{\circ} \mathrm{C}$ and will be discussed in light of its relevance to natural systems. 